\title{
Stipulosina new genus (Diptera: Sphaeroceridae: Limosininae) from bamboo (Chusquea scandens) stipules in Ecuador
}

\author{
TIFFANY YAU ${ }^{1,2}$ \& STEPHEN A. MARSHALL ${ }^{1,3}$ \\ ${ }^{1}$ School of Environmental Sciences, University of Guelph, Guelph, Ontario, Canada N1G $2 \mathrm{Wl}$ \\ 2 "'tyau@alumni.uoguelph.ca; @ https://orcid.org/0000-0001-7458-3462 \\ ${ }^{3}$ |"samarsha@uoguelph.ca; @ittps://orcid.org/0000-0002-5732-9718
}

\begin{abstract}
The new genus Stipulosina (Sphaeroceridae: Limosininae) is described for four new species, S. amphibarba n. sp. (type species), S. barbistylus n. sp., S. ceroptistylus n. sp. and S. curvistylus n. sp., collected from bamboo stipules in the Ecuadorian Andes in 2002 and 2019. All four species are associated with stipules of the Andean bamboo Chusquea scandens Kunth but not with those of sympatric bamboo species.
\end{abstract}

Key words: Neotropical, cloud forests, habitat specialization, Andes

\section{Introduction}

The four related species of Limosininae described here were first collected in May 2002, from bamboo stipules at about $2200 \mathrm{~m}$ in the northeastern foothills of the Ecuadorian Andes at SierrAzul Ecolodge, Napo Province, Ecuador $\left(0^{\circ} 40^{\prime} 5^{\prime} \mathrm{S}, 77^{\circ} 53^{\prime} 50^{\prime} \mathrm{W}\right)$. They were recognized as a distinct genus under the manuscript name Stipulosina shortly thereafter, but publication of the genus was delayed pending opportunities to further investigate its composition and apparent habitat restriction. In 2019 we were able to flesh out the Stipulosina story during a University of Guelph field course at Yanayacu Biological Station, a site close to SierrAzul and with similar stands of bamboo. At that time, three of the four Stipulosina species were again found in the same restricted stipule habitat, and further observations were added to the original collection data. No additional Stipulosina species were found in 2019. Stipulosina species remain known only from bamboo stipules, but we are now able to better document their association with one bamboo species, Chusquea scandens Kunth.

Stipulosina species keys out at couplet 76 of the key to Neotropical Sphaeroceridae genera in Marshall \& Buck (2010). Unlike the species of Archiceroptera Papp that come out at the same point in the key, Stipulosina species have two pairs of dorsocentral setae, two large interfrontal setae, unmodified female terminalia with setose cerci, and the costa running far beyond the apex of $\mathrm{R}_{4+5}$. As discussed below, Stipulosina is probably more closely related to Chespiritos Marshall than to Archiceroptera and related genera.

\section{Materials and methods}

Terminology. Terminology for genitalic structures follows Yau \& Marshall (2018), other morphological terminology follows Cumming \& Wood (2017).

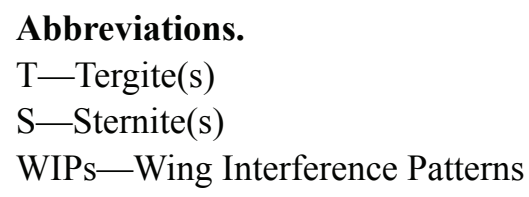


Acronyms of depositories. DEBU (School of Environmental Sciences, University of Guelph, Guelph, Ontario, Canada); QCAZ (Departamento de Biología, Pontífica Universidad Católica del Ecuador, Quito, Ecuador).

All known Stipulosina specimens were collected, either by hand (literally, using a finger dipped in alcohol) or with an aspirator, from bamboo stipules in the northeastern foothills of the Ecuadorian Andes. Several bamboo species from both high $(2000-2200 \mathrm{~m})$ and medium $(\sim 1100 \mathrm{~m})$ elevations were searched for Sphaeroceridae in 2019. Plant species searched for flies include Bambusa vulgaris var. vittata (Rivière \& C.Rivière) McClure, Guadua angustifolia Kunth, Pennisetum banbusiforme (Pourn.) Hemsl, Rhipidocladum racemiflorum (Steud.) McClure, and other unidentified Poaceae. Bamboo species were identified by using keys to genera and species of South America (Ruiz-Sanchez et al., 2015; Calderón \& Soderstrom, 1980). Fly specimens were collected into 70\% (in 2002) or 95\% (in 2019) alcohol and then later dried in a critical point drier and point mounted. Male and female terminalia were examined after clearing whole abdomens, either in hot $10 \% \mathrm{KOH}$ solution and subsequent neutralization in glacial acetic acid or in enzymatic contact lens cleaner solution (used according to package directions) and subsequently rinsed in deionized water (Yau \& Marshall, 2015). Cleared structures were preserved in glycerin and pinned below specimens in microvials.

DNA sequencing. Twelve (four each of $S$. amphibarba n. sp., S. barbistylus n. sp., S. ceroptistylus n. sp.) specimens collected in 2019 were sent to the University of Guelph Biodiversity Institute of Ontario for sequencing (Ivanova et al., 2006; Hebert et al., 2013; Prosser et al., 2016) of the $5^{\prime}$ region of the Cytochrome $c$ Oxidase I mitochondrial gene (COI) (DNA barcode region). All twelve sequenced equally well and one representative from each of the three species was used in the maximum likelihood analysis (Table 1).

Sequence data for 68 Limosininae specimens (not including the three Stipulosina representatives) were selected from the BOLD database for maximum likelihood analysis based on the quality of sequences (500 bp or greater) (Table 1). Sequences were aligned by BOLD Aligner. Identifications of the specimens were confirmed or corrected using morphological characters.

The maximum likelihood analysis was performed using IQ-Tree (Nguyen et al., 2015) on the CIPRES Science Gateway v3.3 computing cluster (Miller et al., 2010). The dataset was unpartitioned, GTR+F+I+G4 was determined to be the best-fit model of evolution by ModelFinder (Kalyaanamoorthy et al., 2017), and branch supports were obtained with the ultrafast bootstrap algorithm (Hoang et al., 2018). The ML tree was rooted on Copromyza equina, the only Copromyzinae included as an outgroup to the Limosininae. The output tree was visualized and exported as a PDF file in FigTree (Rambaut, 2009) and subsequently visually enhanced in Adobe Illustrator CC.

The analysis of barcode data is used to test the monophyly of Stipulosina and its postulated relationships with other taxa as suggested by morphological data. Broader consideration of other taxa across the Limosininae topography is outside the scope of this project, but we note that the DNA barcode region alone, at least with currently available sequences, does not provide stable, consistent resolution to tree topography. This may be a result of both poor sampling at the inter- and infra-generic level, and insufficient phylogenetic signal within the COI gene of Limosininae.

Biology: All but one of the 166 Stipulosina specimens collected in 2019 were collected only from Chusquea scandens Kunth (Poaceae). The one exception was found on a Rhipidocladum racemiflorum stem close to a cluster of Chusquea scandens. Numerous nearby R. racemiflorum were searched intensively for further sphaerocerids without success. No Stipulosina specimens were found among the several thousand sphaerocerids collected in pan traps, flight intercept traps and dung traps set nearby in both 2002 and 2019, nor have any specimens been found in trap samples taken in similar habitats elsewhere.

Most Stipulosina adults were collected on young bamboos just starting to bud at the nodes, with buds no longer than a few inches (Fig. 4). Stipules at this stage are usually orangish-tan in color and slightly separated from the culm by budding branches, with little decomposition of vascular tissue in the stipules (Fig. 5).

Chusquea scandens have fleshy stipules that are pushed outwards at the base by the distinctive budding at the nodes, creating tent-like shelters that hold moisture and a bit of decomposing vascular tissue. This contrasts with the thin, fibrous, tightly wrapped stipules of other bamboo species, which apparently do not accommodate Stipulosina. As the bamboo matures, flies occur on progressively higher stipules, suggesting a correlation between the "maturity" of the stipules and the presence of flies. Isolated or non-crowded bamboo stems had significantly more flies. Stipulosina pairs (one pair caught and identified as S. barbistylus) were observed in copula on the stipules but oviposition was not observed, and we were unable to find immature stages. Larvae or pupae of Chloropidae, Phoridae, Muscidae, Cecidomyiidae and Drosophilidae were found in stipules but, remarkably, no Sphaeroceridae. 


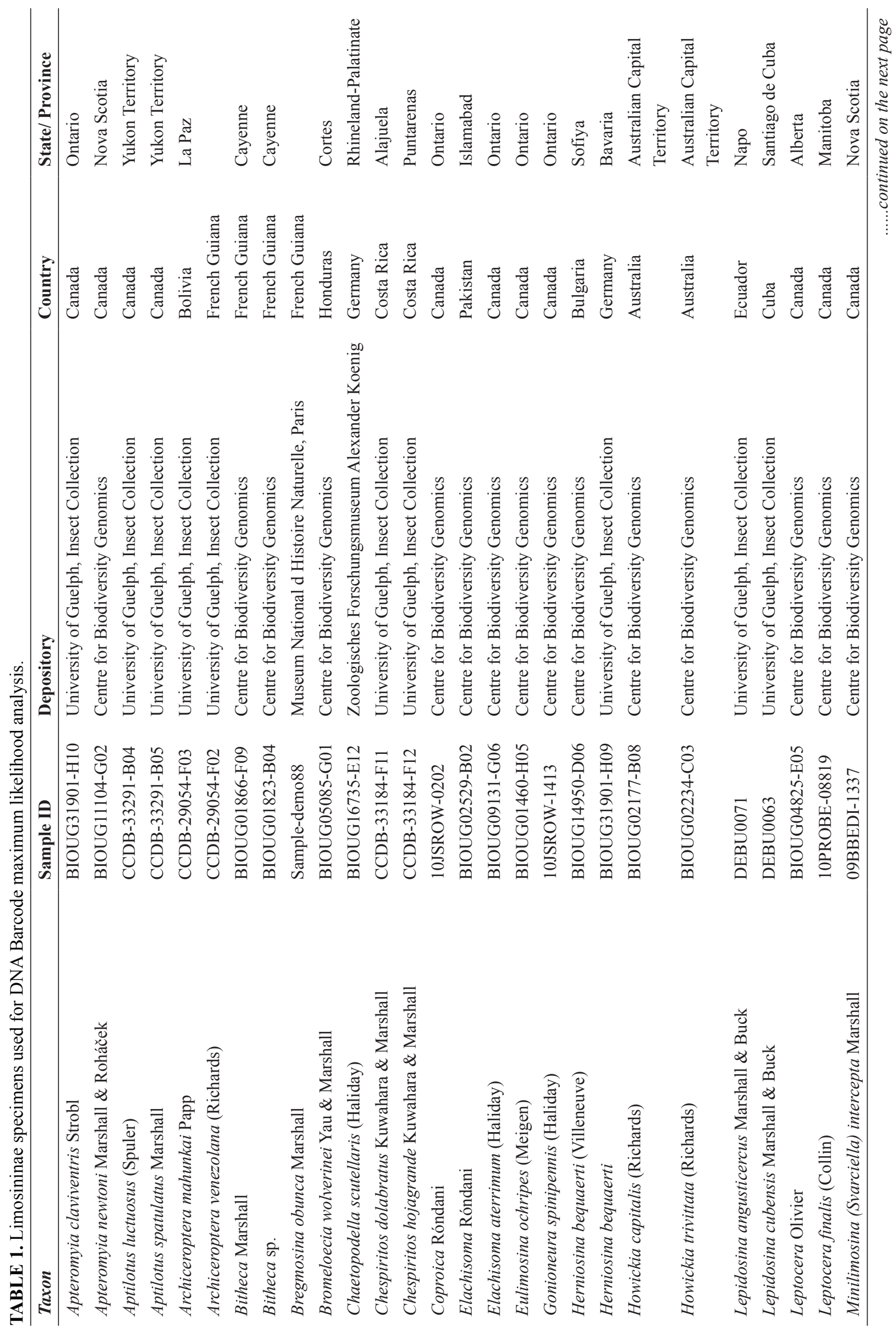

NEW GENUS STIPULOSINA (SPHAEROCERIDAE: LIMOSININAE)

Zootaxa 5072 (3) (C) 2021 Magnolia Press · 257 


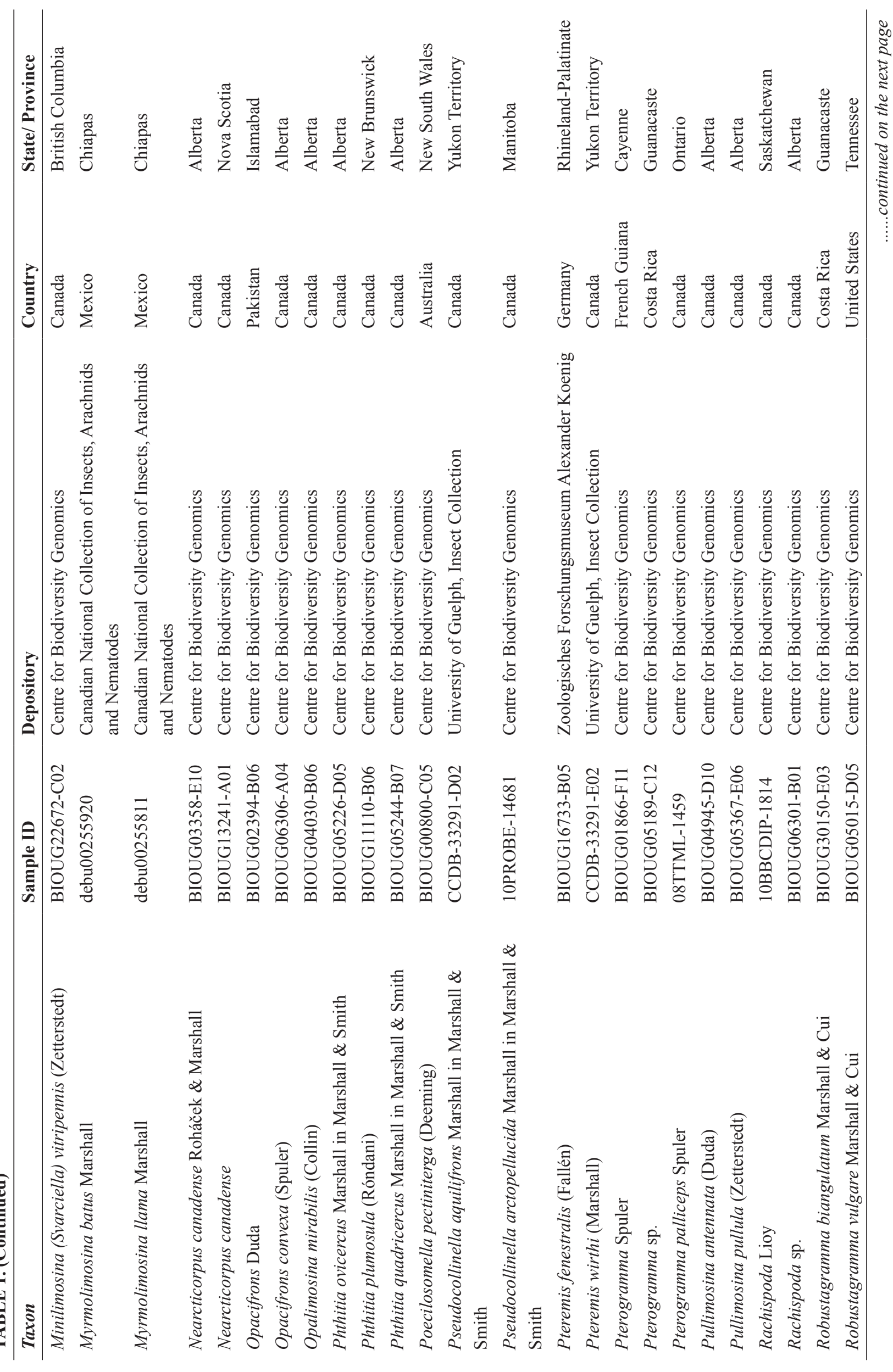




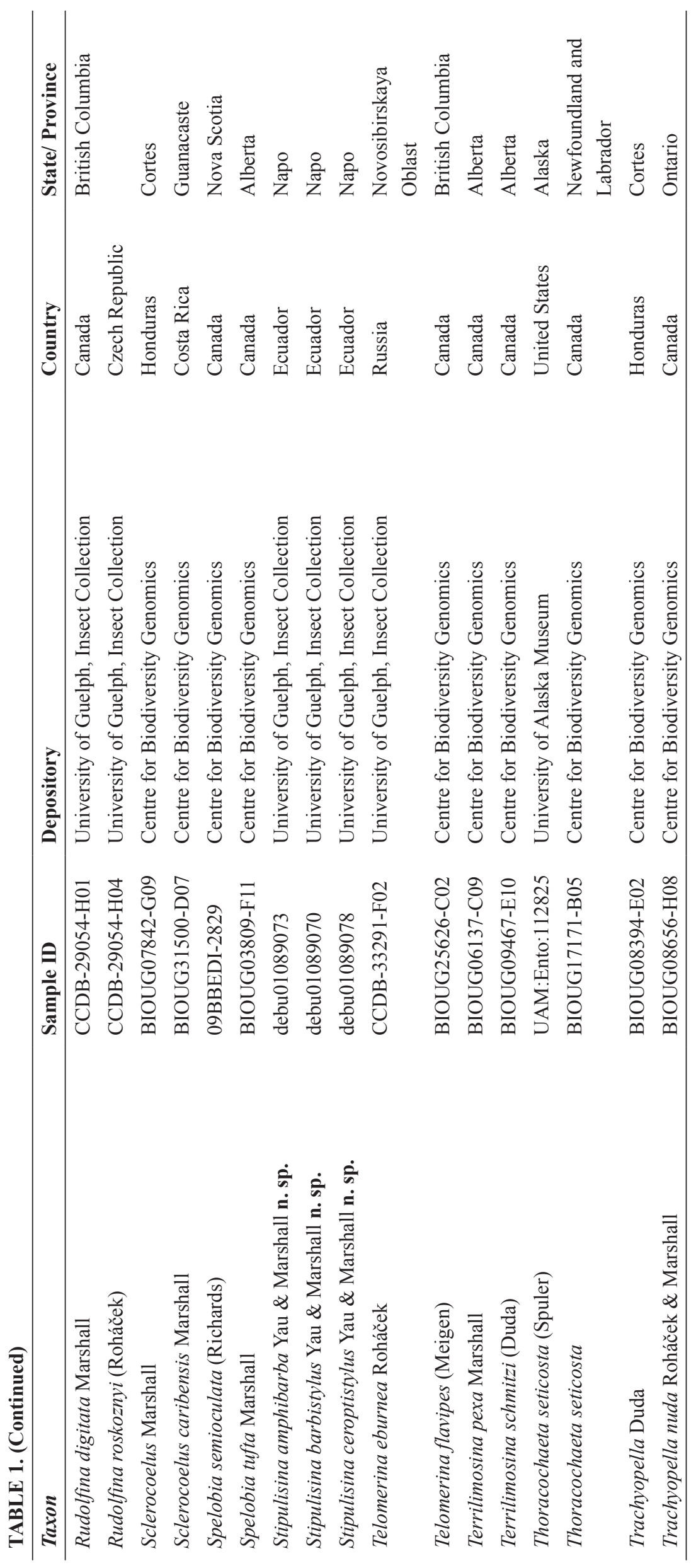

NEW GENUS STIPULOSINA (SPHAEROCERIDAE: LIMOSININAE)

Zootaxa 5072 (3) ( 2021 Magnolia Press · 259 


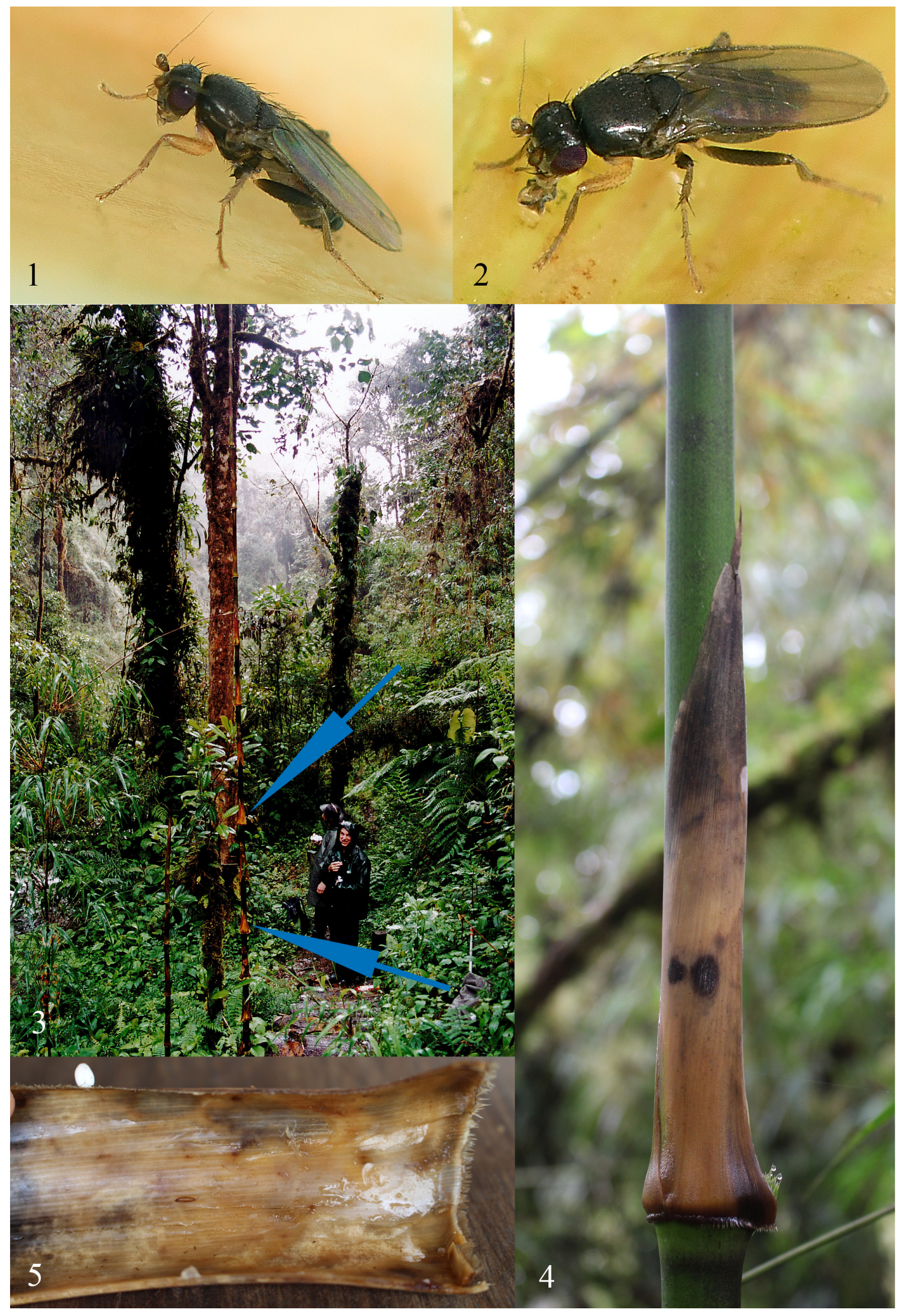

FIGURES 1-5. 1 \& 2, Stipulosina sp. male, living flies on stipule tissue (staged); 3, Type locality of Stipulosina (arrows indicate bamboo stipules in which the type specimen of $S$. amphibarba n. sp. was found), photographed by Steven Paiero as the type specimens were being collected in 2002; 4 \& 5, Chusquea scandens stipules at the growth stage most attractive to Stipulosina (puparium in photo identified as Drosophilidae by DNA-barcoding). 
Relationships: Several characters, including the cruciate interfrontal setae, costa extending far beyond the apex of $\mathrm{R}_{4+5}$, the relatively broad face and mid leg chaetotaxy suggest a relationship to species of Chespiritos, which normally differ conspicuously from Stipulosina in having six scutellar setae although the basal pair of scutellar setae is absent in Chespiritos calceus Kuwahara \& Marshall (2020). Chespiritos species also have the portion of the costa beyond $\mathrm{R}_{4+5}$ relatively short and have weaker proximal, distal posterodorsal and distal small dorsal (above distal large dorsal) midtibial setae. Chespiritos and Stipulosina both have a relatively simple, robust, heavily sclerotized basally tubular distiphallus, but other characters of the male terminalia differ. Chespiritos species have simple male cerci joined by a subanal plate, characteristic additional sclerites between S5 and S6, and a differently configured hypandrium in which the posterolateral arms are fused with the anteromedian process. Females of both genera have T8 medially desclerotized but entire and S7 large and shield-like, but the epiproct is entirely absent in Chespiritos and present in Stipulosina.

The maximum likelihood tree (Fig. 17) showed the Stipulosina species in a single strongly supported branch and recovered a sister clade made up of Chespiritos, Bitheca Marshall, Pullimosina Roháček and Coproica Róndani, but with weak support for the clade itself and its relationship to Stipulosina. As mentioned in the previous section, the current available molecular data is insufficient for resolving higher classification, thus the recovery of a poorly supported sister clade is unsurprising. Bitheca is a distinct group morphologically, with several synapomorphies including an unusual reduced number of spermathecae in females and unique phallic sclerites in males. Bitheca species are distinct from Chespiritos and Stipulosina in having small interfrontals, different leg chaetotaxy, simple female S7, and a large S8 and hypoproct. Pullimosina have cruciate interfrontals like Chespiritos and Stipulosina, but have different leg chaetotaxy, male distiphallus segmentation, and a female abdomen that normally has an additional sclerite between S8 and the hypoproct. Coproica is easily separated from related genera by its setose scutellar disc.

Unlike almost all other Sphaeroceridae, Chespiritos, Bitheca, Pullimosina and Stipulosina are not normally taken in dung traps. Chespiritos and Pullimosina species are associated with decaying vegetation, Bitheca species are usually associated with fungi, and we establish here that Stipulosina are strongly associated with bamboo stipules.

\section{Stipulosina Yau \& Marshall new genus}

\section{Type species: Stipulosina amphibarba new species}

Generic diagnosis. Stipulosina species are characterized by two pairs of cruciate interfrontal setae, two pairs of dorsocentral setae, four scutellar setae, sexually dimorphic mid tibia, and the costa extending far beyond the apex of $\mathrm{R}_{4+5}$. Males have a characteristic sternite 5 (S5) with a trifid posteromedial margin, and stout, bilaterally symmetrical hypandrial arms separate from both the epandrium and the central part (anterior apodeme) of the hypandrium.

Generic description. Antenna to wing tip length $1.8-2.8 \mathrm{~mm}$; wing fully developed, extending far beyond tip of abdomen and twice as long as wide. General color brown, legs mostly pale brown to yellowish (hind femur brown).

Head: Face broad and flat, lunule broadly rounded and as wide as distal margin of pedicel. Clypeus narrow, strap-like. Palpus short, pale, with one or more preapical ventral setae. Eye $2.5-5 \times$ as high as gena; vibrissa long; gena with 1-3 upturned setae in addition to the small marginal setae, anterior genal seta longer than genal height. Antenna yellowish brown, margin of pedicel with long setae, arista long-pubescent and almost twice as long as head height. Frons with dark stripes surrounding base of interfronal setae, forming a M pattern more or less interrupted anteromedially. Interfrontal area broad, flanked by two pairs of cruciate interfrontal setae and a pair of small lower setulae. Fronto-orbital setae large and lateroclinate, lower pair about $0.7 \times$ upper pair, small exclinate orbital setulae present. Ocellar and outer vertical setae large and subequal; inner vertical seta very large; postocellar setae very small, inner and outer occipital setae large.

Thorax: Prosternum linear, bare. Fore femur with several long, thin posterodorsal and ventral setae. Mid tibia of both sexes with a distinct ventral seta before middle and a long apicoventral seta; male mid tibia with a row of stout ventral setae on distal half and corresponding enlarged setae in the basal half of the femur. Hind leg with first tarsomere swollen, less than half as long as second, first and second tarsomeres densely golden setulose ventrally; hind tibia with neither a distinct apical spur nor enlarged dorsal setae; hind femur slightly to strongly swollen. 
Scutum pruinose, with two strong postsutural dorsocentral setae; prescutellar acrostichal setulae twice as long as other acrostichals. Postpronotal lobe with a single very large outer seta and a small inner seta; notopleural, supraalar and postalar setae strong, intra-alar slightly enlarged. Scutellum wider than long, with four long marginal setae. Katepisternum with one large dorsal seta and one or two very small setae.

Wings with white to pale brown veins and a small, narrow, apically rounded alula. Vein $\mathrm{R}_{2+3}$ weakly sinuate, apex strongly curving up to costa; $\mathrm{R}_{4+5}$ evenly curved up to meet costa well before wing tip, costa extending far beyond apex. Ventral costagial seta long.

Male abdomen: Sternite 5 short to long but always with a strongly developed tripartite posterior margin with a small, dark central process flanked by two larger setose lobes. Sternite 8 (S8) very short, fused to sternite 6+7 (S6+7) on right side. Subepandrial sclerite well developed, functionally replacing weak subanal plate. Cercus variable, short and fused to epandrium or sometimes more separate and elongate, but always with strong setae. Surstylus highly variable between species. Hypandrial arm free from main (medial) part of hypandrium and from epandrium. Phallic complex compact and heavily sclerotized.

Female abdomen (female unknown for S. curvistylus): Tergite 7 (T7) half as wide as and slightly shorter than tergite 6 (T6), sometimes posteriorly emarginate. Tergite 8 (T8) entire, approximately equal in width to T7. Epiproct weakly sclerotized, bare. Cercus elongate, apically long-setose. Sternite 7 (S7) very large and well sclerotized, at least 1.5× length of sternite 6 (S6) and normally concealing S8. S8 short, strap-like with four setae. Hypoproct separated, on each side ventral to cerci and posterior to margins of T8. Three $(2+1)$ small, short spermathecae, bodies no longer than wide.

Etymology: The generic name is derived from a combination of the name of the structure in which these flies occur and the "-sina" suffix that has become usual for generic names in the Limosininae. The gender is feminine.

\section{Key to the species of Stipulosina}

1) Eye height less than $3 \times$ genal height (Fig. 15c). Hind tibia with some enlarged dorsal setae on distal half; hind femur similar in color to hind tibia and weakly swollen, about twice the diameter of the tibia (Fig. 15a). Surstylus with a single long curved lobe with three stout preapical setae (Fig. 16a) ............. Stipulosina curvistylus new species, known only from one male. Eye height greater than $4 \times$ genal height (Figs. 6c, 9c, 12c). Hind tibia with only uniformly small dorsal setae; hind femur darker than hind tibia and conspicuously swollen, at least $3 \times$ the diameter of the hind tibia (Figs. 6a, 9a, 12a). Surstylus either broad and densely setose (Figs. 7a, 10a) or slender and deeply bifid (Fig. 13a), never curved with stout preapical setae. . . . . . 2

2) Proximal posterodorsal mid tibial seta small, $0.6 \times$ the length of anterodorsal seta at same level (Fig. 12e). Cercus reduced to posteroventral corner of epandrium but with conspicuously thick setae (Figs 13a, c). Subepandrial plate broad, triangular or T-shaped (Fig. 13c). Surstylus deeply cleft, U-shaped (Fig. 13d), with two long, narrow, sparsely setose ventral lobes. ......

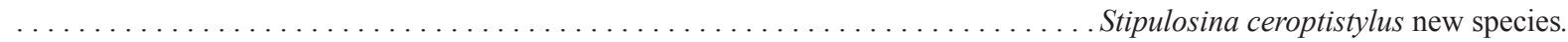
Proximal posterodorsal mid tibial seta large, $0.75 \times$ the length of anterodorsal seta at same level (Figs. 6e, 9e). Cercus separate, elongate and setose (Figs. 7c, 10d). Subepandrial plate somewhat X-shaped (Figs. 7c, 10d). Surstylus bilobed but not deeply

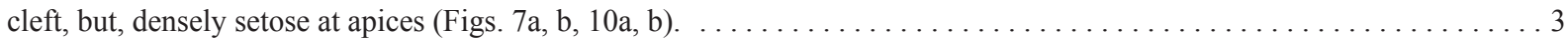

3) Male cercus longer than surstylus, setae at apex of cercus much longer than surstylar setae (Fig. 7a). Lateral margins of female T8 dilated, conspicuously longer than dorsal part of sclerite (Fig. 9c) ............ Stipulosina amphibarba new species. Male surstylus longer than cercus, setae on ventral margin of surstylus longer than setae on cercus (Figs. 10a, e). Lateral margins of female T8 only slightly dilated, not conspicuously longer than dorsal part of sclerite (Fig. 11c) $\ldots \ldots \ldots \ldots$

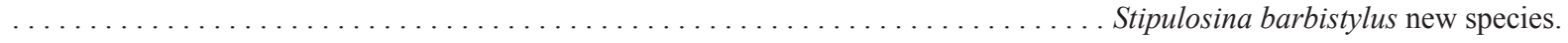

\section{Species descriptions}

\section{Stipulosina amphibarba Yau \& Marshall n. sp.}

(Figs. 6a-e, 7a-d, 8a-d)

Description: Body length 2.0-2.8 mm, males and females similar in size. General color brown but leg parts other than hind femur yellow. Eye height $5 \times$ genal height. Mid tibia with a pair of equal setae at basal quarter with posterodorsal seta at least half as long as anterodorsal seta; anterodorsal, dorsal and smaller posterodorsal setae at distal 3/4. Wing veins pale, whitish. Third costal sector subequal to second.

Male abdomen: Sternite 5 with a prominent trifid posteromedial area made up of a small, distally bilobed central piece with a cluster of dense setae on each side; flanked by longer processes with a narrow, pointed outer margin; 


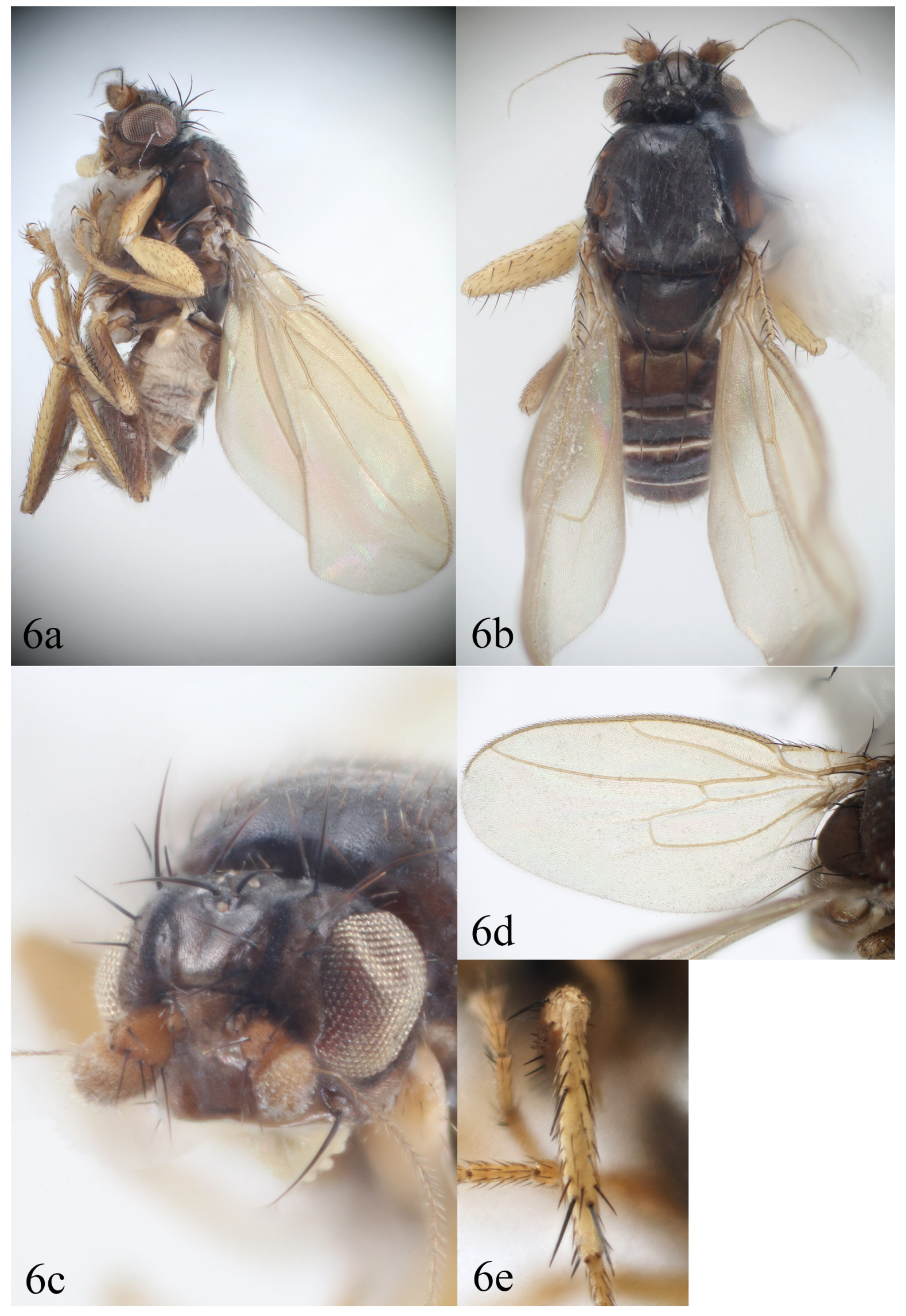

FIGURES 6a-e. Stipulosina amphibarba sp. n. male habitus. 6a, lateral; 6b, dorsal; 6c, head; 6d, wing against white background; 6 e, mid tibia dorsal. 


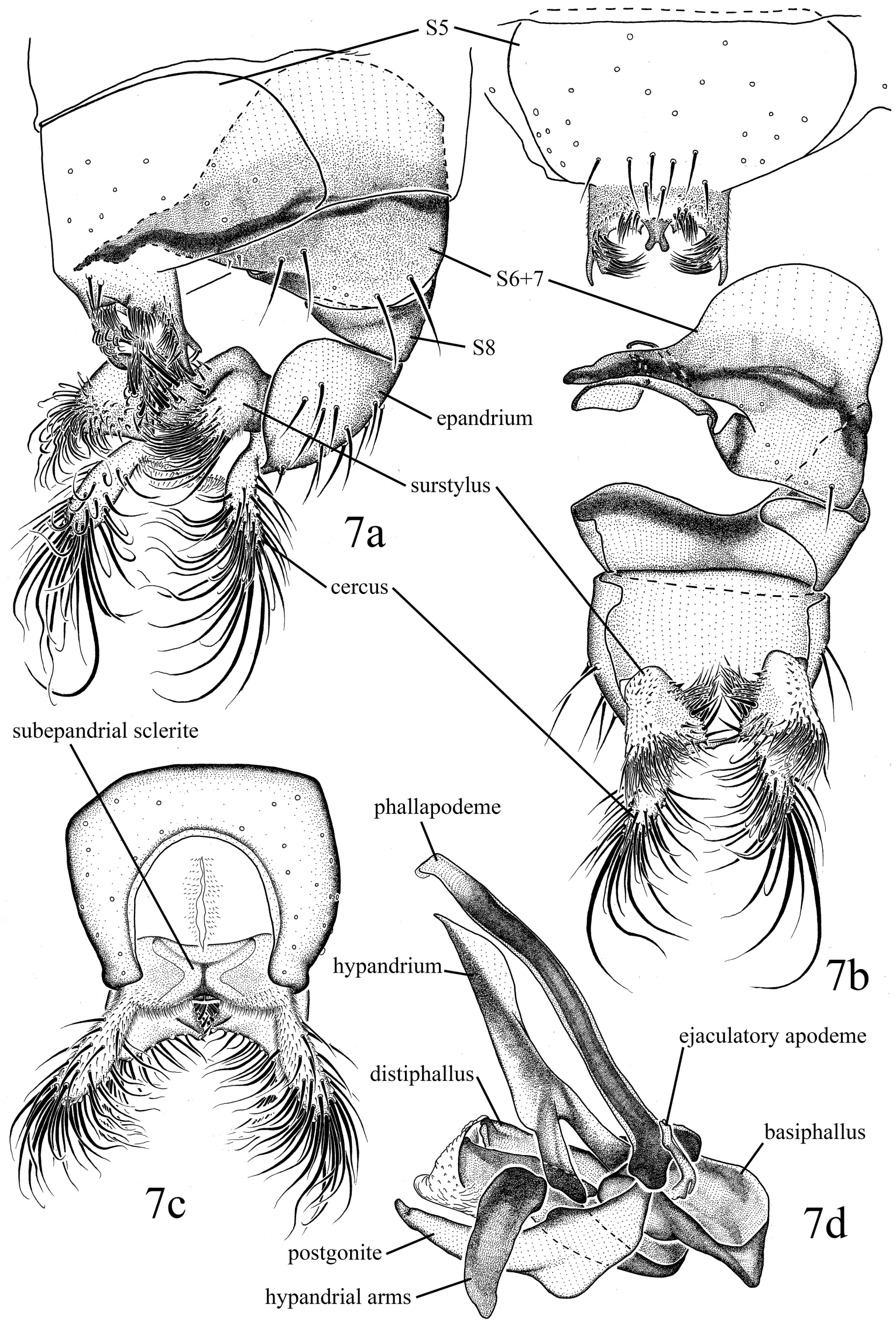

FIGURES 7a-d. Stipulosina amphibarba sp. n. male abdomen. 7a, terminalia left ventrolateral; 7b, terminalia ventral; 7c, epandrium posterior; $7 \mathrm{~d}$, phallus and associated structures left dorsolateral. 


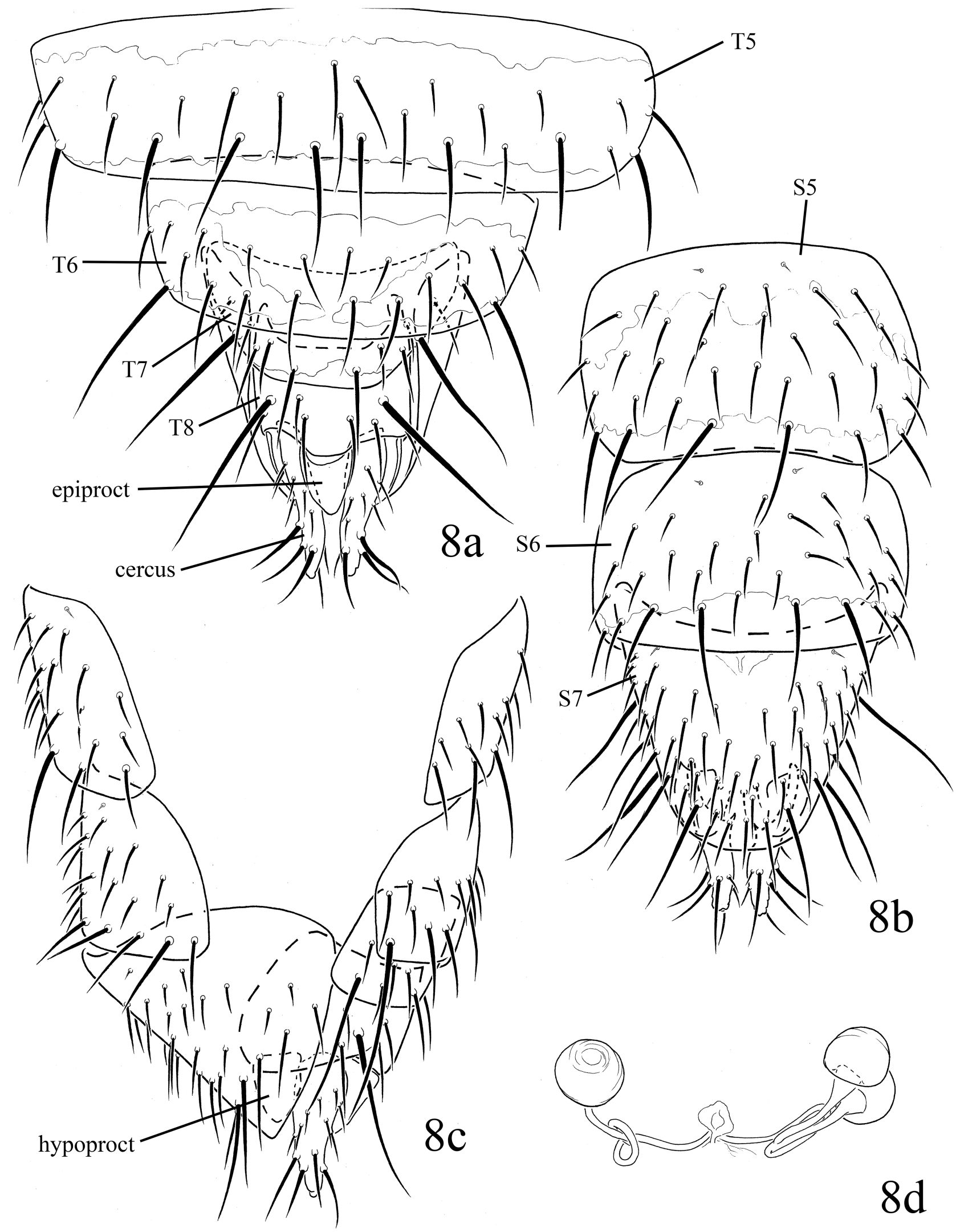

FIGURES 8a-d. Stipulosina amphibarba $\mathbf{s p . ~ n . ~ f e m a l e ~ a b d o m e n . ~ 8 a , ~ t e r m i n a l i a ~ d o r s a l ; ~ 8 b , ~ t e r m i n a l i a ~ v e n t r a l ; ~ 8 c , ~ t e r m i n a l i a ~}$ lateral; 8d, spermathecae. 
inner margin of process with a long-setose lobe. Sternite 5 length anterior to trifid posteromedial area subequal to length of S4. Epandrium with uniform setae. Cercus robust and conspicuously long-setose at apex, length 1.2-1.3× surstylus length. Surstylus stout and triangular; ventral lobe densely setose, dorsomedial lobe with thick tuft of setae (often hidden between/ behind posteromedial lobe of S5). Basiphallus broadly cylindrical; distiphallus very short and broad, mostly sclerotized except at apex. Postgonite stout, broad basally and tapered apically.

Female abdomen: Tergite 8 desclerotized medially or just posteromedially; tergite length at margins $1.25 \times$ medial length of tergite. Epiproct half as long as cercus. Spermathecae smooth except few creases on dorsal surface.

Type material: Holotype ( $\widehat{\jmath}$, QCAZ): ECUADOR: Napo: SierrAzul Reserve, 14 km W Cosanga, $2200 \mathrm{~m}$, in bamboo stipules, 11.v.2002, S.A. Marshall debu00195517.

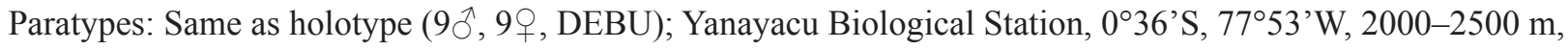
25.ix-13.x.2019, T. Yau and S.A. Marshall (6ㅅ, 8ㅇ, QCAZ).

Etymology: The specific name refers to the bearded surstylus and cercus.

Comments: Males of S. amphibarba and S. barbistylus are easily differentiated by the relative lengths of the large, heavily setose cerci and surstyli, which are usually visible even in dried specimens. Females of these two species are similar, but females of the closely related S. barbistylus (taken in copula with the easily identified male) have a T8 with dilated lateral margins. The remaining female specimens, with subequal medial and lateral lengths of T8, are assumed to be $S$. amphibarba.

\section{Stipulosina barbistylus Yau \& Marshall n. sp.}

(Figs. 9a-e, 10a-g, 11a-d)

Description: As described for S. amphibarba n. sp. except as follows:

Male abdomen: Trifid posteromedial area with small clusters of setae on each side of center piece; longer processes flanking center piece long-setose on distal half inner margin. Cercus length $0.6-0.7 \times$ surstylus length. Ventral lobe of surstylus broad and flat, densely long-setose at distal half; dorsomedial lobe small, apex with a few stout setae followed by tight rows of setae along margin. Distiphallus cylindrical with dorsolateral edges strong and corrugated; apex membranous. Postgonite stout, broad basally and tapered apically.

Female abdomen: Tergite 8 posteromedially desclerotized; medial and lateral lengths subequal. Length of epiproct $0.5 \times$ length of cercus. Spermathecae irregularly crinkled.

Etymology: The specific name refers to the dense "beard" of long distal setae on the surstylus.

Type material: Holotype ( $\widehat{\jmath}, \mathrm{QCAZ})$ : ECUADOR: Napo: SierrAzul Reserve, $14 \mathrm{~km}$ W Cosanga, $2200 \mathrm{~m}$, 040'55'S, 7756'9'W, in bamboo stipules, 11.v.2002, S.A. Marshall debu00195526.

Paratypes: ECUADOR: Napo: Yanayacu Biological Station, 0³6’'S, 7753’'W, 2000-2500 m, 25.ix-13.x.2019, T. Yau and S.A. Marshall (63 $\hat{0}, 55$, QCAZ); same as previous specimens but the female and male were taken in

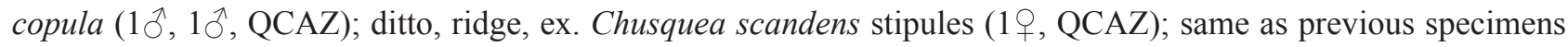
but on Rhipidocladum racemiflorum (19, QCAZ).

Comments: The one specimen of this species collected from Rhipidocladum racemiflorum is the only specimen of the genus known from a species of bamboo other than Chusquea scandens. That specimen was found on a stem rather than in a stipule and it is unlikely to represent a close association. The $R$. racemiflorum on which the specimen was found on was close to C. scandens, and no further Stipulosina specimens were found in an extensive search of nearby $R$. racemiflorum.

\section{Stipulosina ceroptistylus Yau \& Marshall n. sp.}

(Figs. 12a-e, 13a-f, 14a-d)

Description: Body length 1.8-2.8 mm, females on average smaller than males. General color brown but leg parts other than hind femur yellow. Eye height 4.5-5.0× gena height. Mid tibia with an anterodorsal seta at basal quarter, the corresponding posterodorsal seta small and inconspicuous, less than a third as long as anterodorsal seta; anterodorsal, dorsal and smaller posterodorsal setae present at distal 3/4. Second and third costal sectors subequal. 


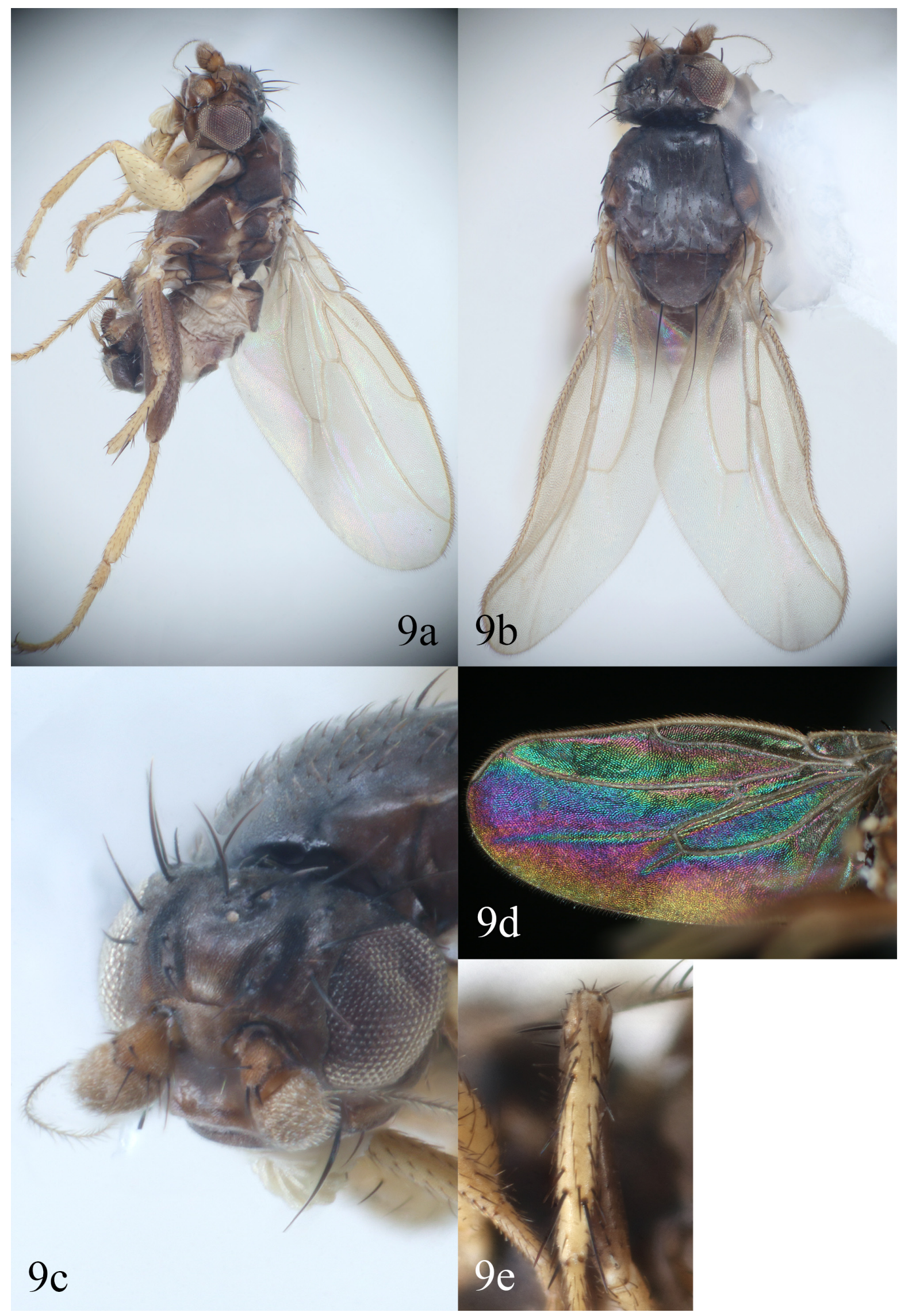

FIGURES 9a-e. Stipulosina barbistylus sp. n. male habitus. 9a, lateral; 9b, dorsal; 9c, head; 9d, wing displaying WIPs against black background; 9e, mid tibia dorsal. 


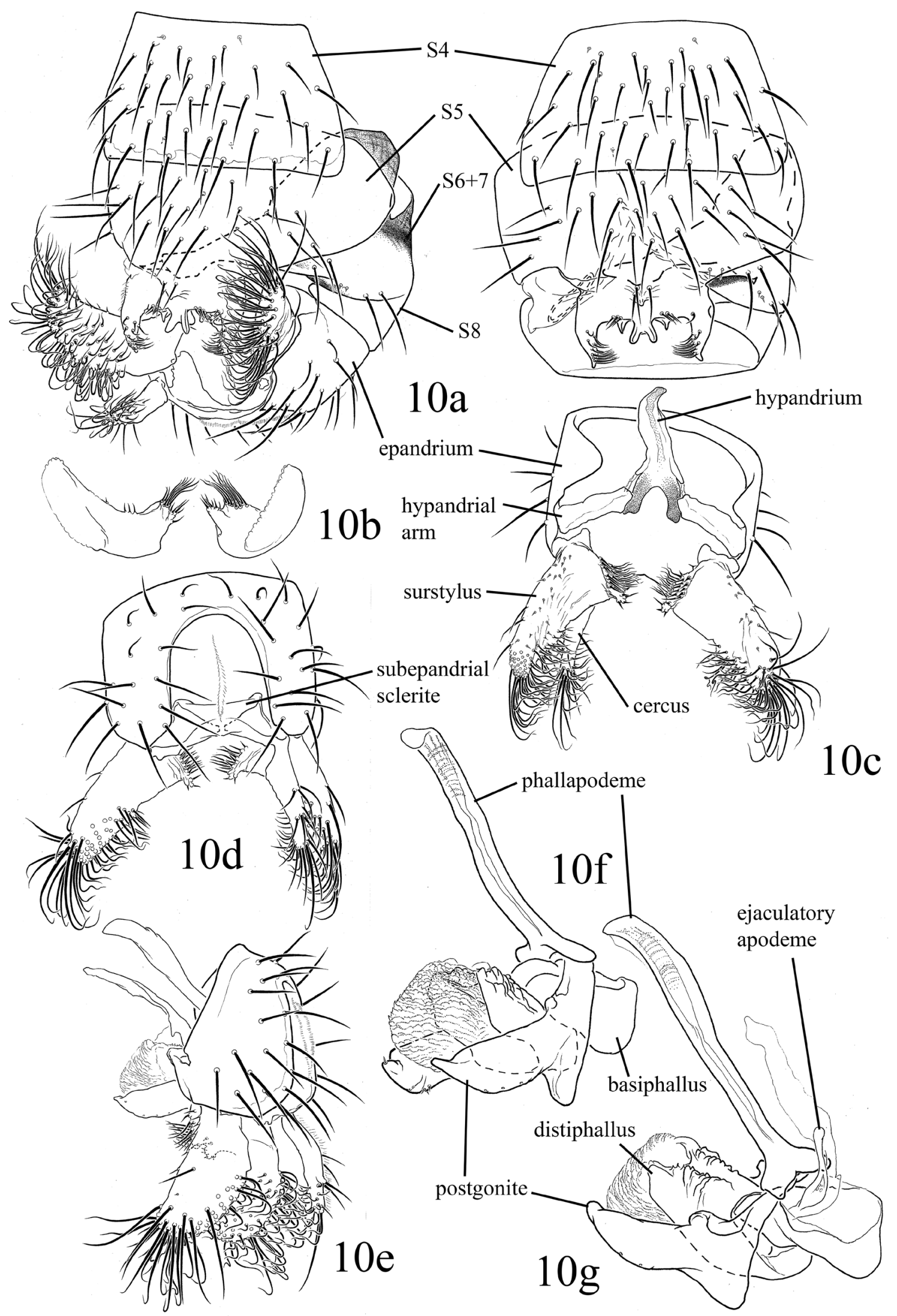

FIGURES 10a-g. Stipulosina barbistylus sp. n. male abdomen. 10a, terminalia left ventrolateral; 10b, surstyli ventrolateral, with setosity of outer lobe omitted to show inner lobe structure obstructed in 10a; 10c, terminalia ventral; 10d, epandrium posterior; 10e, epandrium lateral; 10f, phallus and associated structures left ventrolateral; $10 \mathrm{~g}$, phallus and associated structures left dorsolateral. Note: left cercus is absent in 10a, 10c, 10d and 10e. The cercus was missing (broken off) from the lone specimen at the time of illustration (before the 2019 collection). 


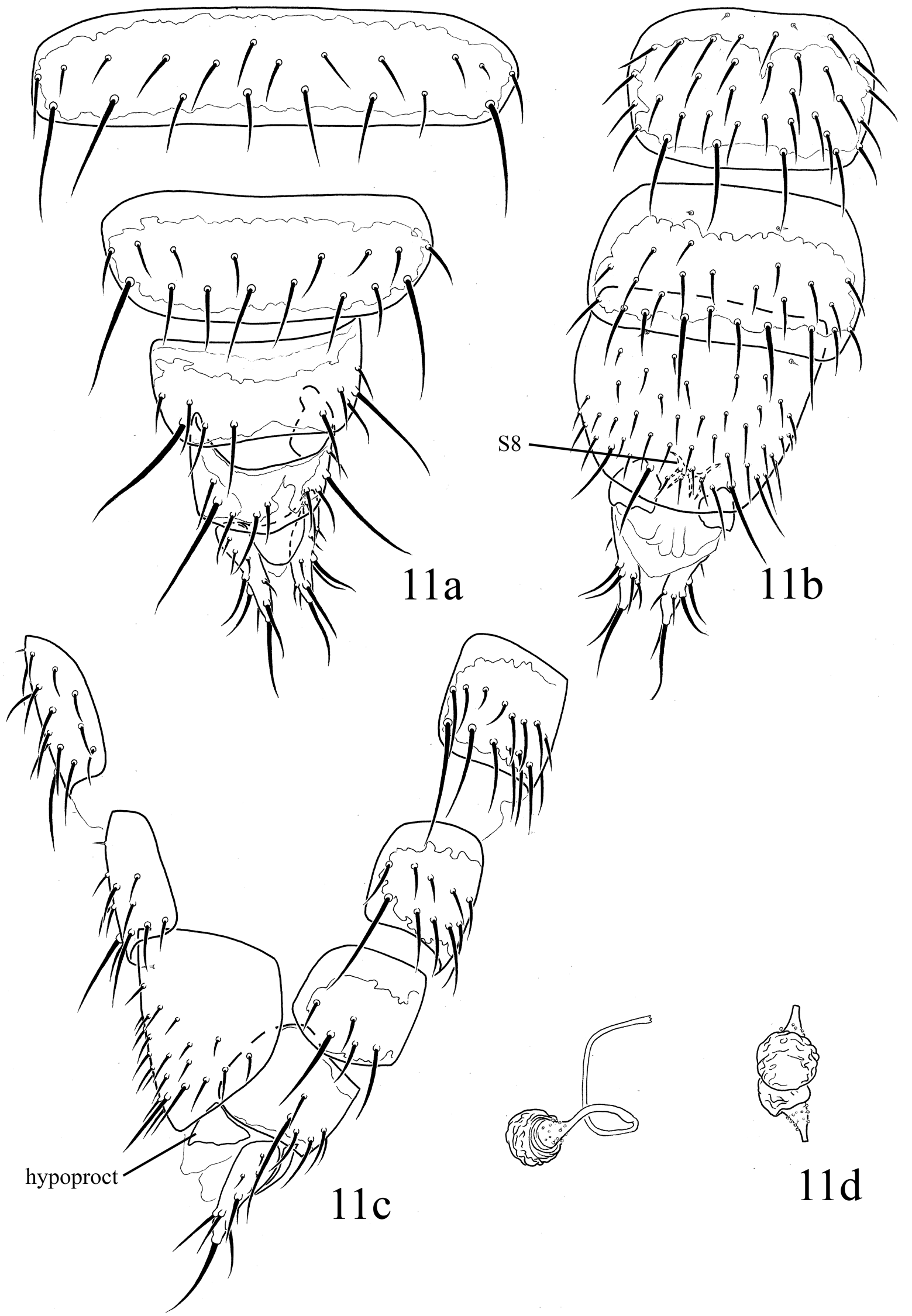

FIGURES 11a-d. Stipulosina barbistylus sp. n. female abdomen. 11a, terminalia dorsal; 11b, terminalia ventral; 11c, terminalia lateral; 11d, spermathecae. 


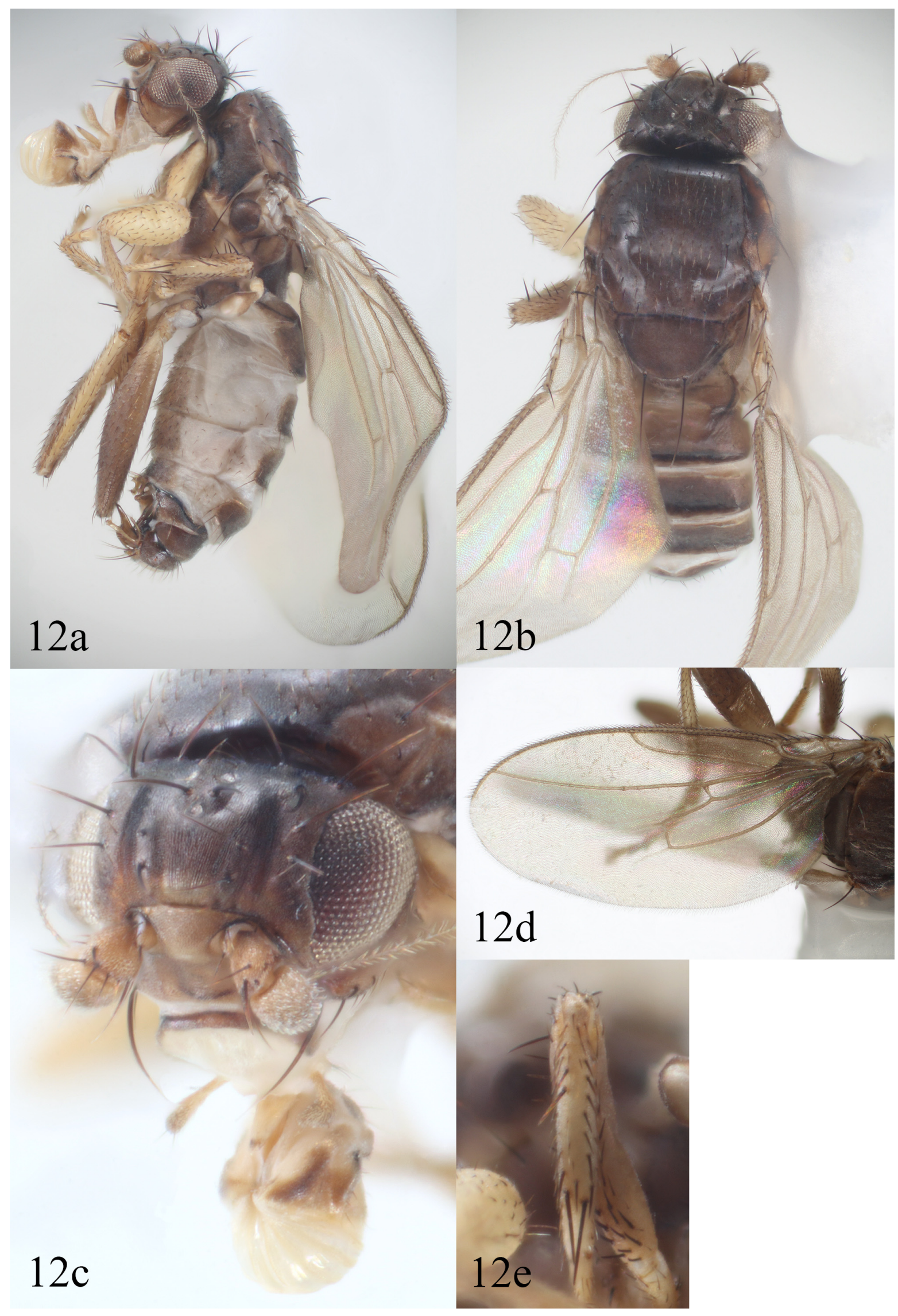

FIGURES 12a-e. Stipulosina ceroptistylus sp. n. male habitus. 12a, lateral; 12b, dorsal; 12c, head; 12d, wing against white background; 12e, mid tibia dorsal. 

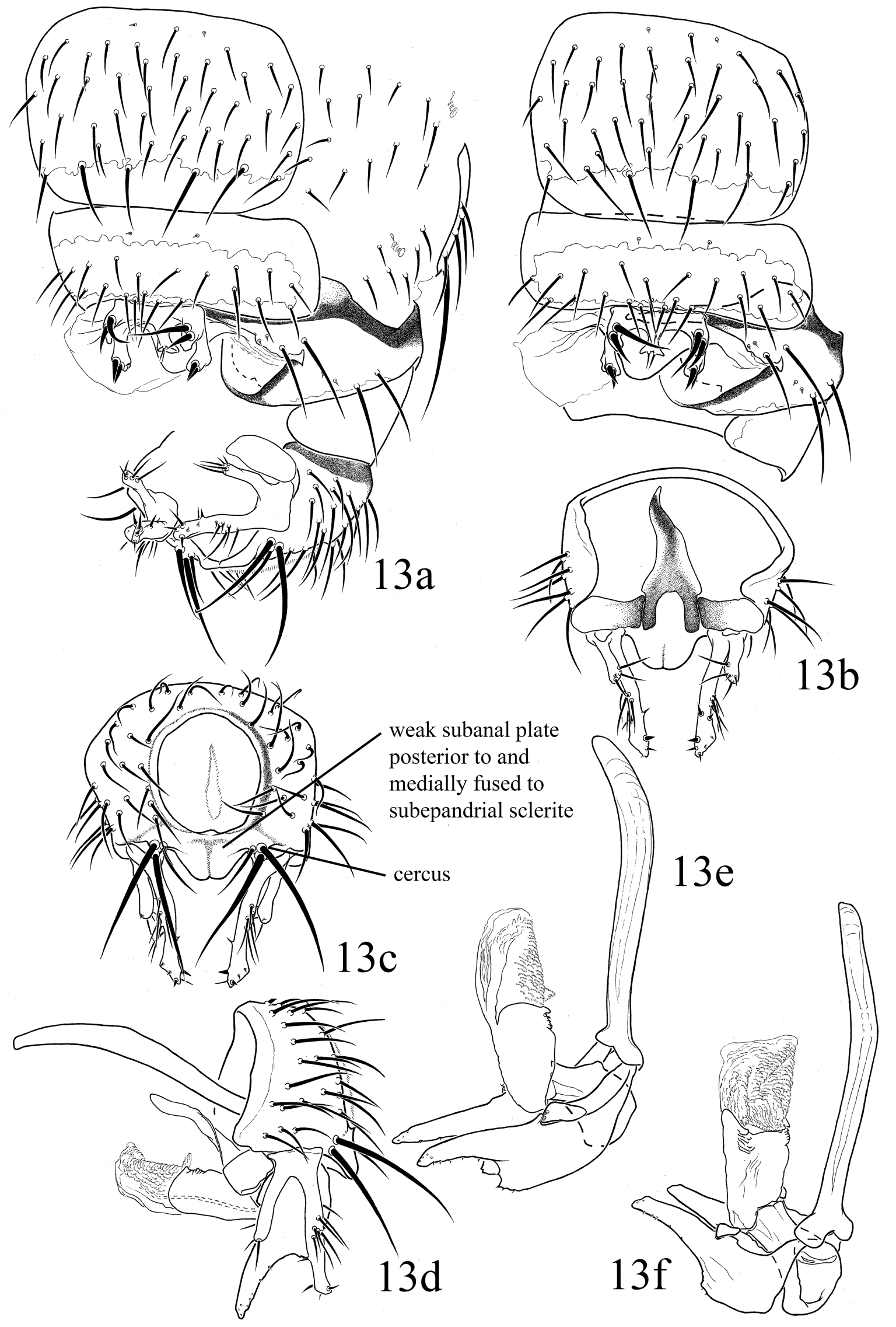

FIGURES 13a-f. Stipulosina ceroptistylus $\mathbf{s p .}$ n. male abdomen. 13a, terminalia left ventrolateral; 13b, terminalia ventral; 13c, epandrium posterior; 13d, epandrium lateral; 13e, phallus and associated structures left ventrolateral; 13f, phallus and associated structures left dorsolateral. 


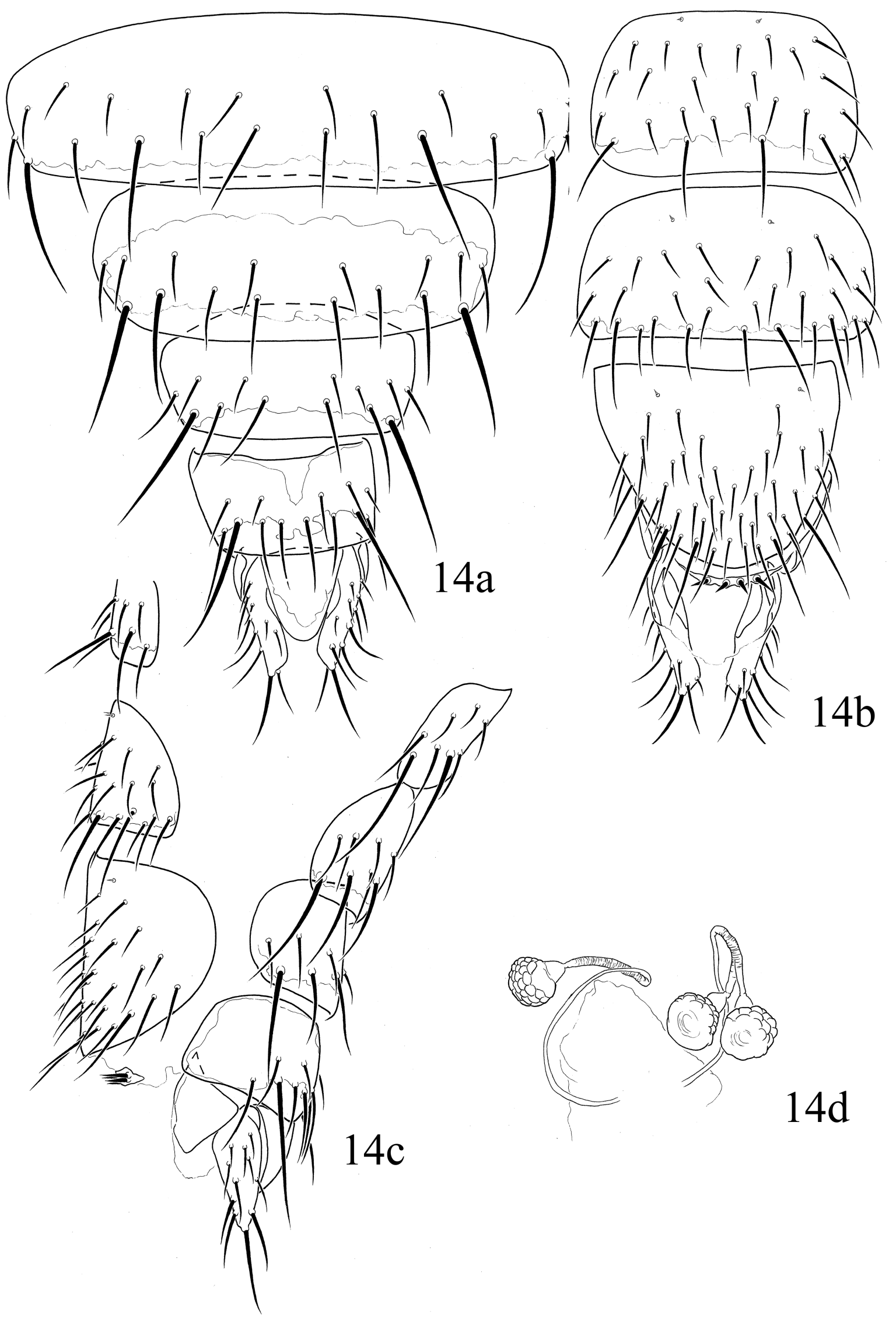

FIGURES 14a-d. Stipulosina ceroptistylus sp. n. female abdomen. 14a, terminalia dorsal; 14b, terminalia ventral; 14c, terminalia lateral; $14 \mathrm{~d}$, spermathecae. 
Male abdomen: Sternite 5 with a prominent trifid posteromedial area made up of a small, distally narrow central piece subtended by a cup-like lobe and flanked by longer processes with broad basal ventral lobe with long stout setae and a distal bare ventral lobe giving the apex a beak-like aspect; length anterior to trifid posteromedial area $0.5 \times$ length of S4. Epandrium with uniform setae. Surstylus deeply divided into elongate, narrow anterior and posterior ventrally directed lobes, both setose but posterior lobe much longer. Cercus small, slightly convex, with two long, stout setae. Ventral lobe of subepandrial sclerite rounded and short. Basiphallus broadly cylindrical, tapered to distiphallus; distiphallus basally cylindrical and heavily sclerotized, dorsally with a straight fork extending to apex of membranous distal portion, membrane finely spiculate ventrally. Postgonite stout, dark; very broad basally, sharply tapered on distal half.

Female abdomen: Tergite 8 anteromedially desclerotized; T8 of uniform length. Epiproct three quarters as long as cercus. Spermathecae with scale-like pattern.

Etymology: The specific name refers to the deeply cleft surstylus, superficially similar to the surstylus of species in the genus Ceroptera Macquart.

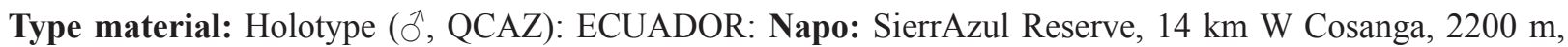
040'55'S, 7756'9”'W, in bamboo stipules, 11.v.2002, S.A. Marshall debu00195553.

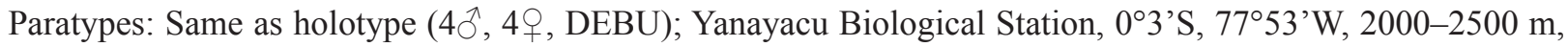
25.ix-13.x.2019, T. Yau and S.A. Marshall (15ð, 15ㅇ, QCAZ).

\section{Stipulosina curvistylus Yau \& Marshall n. sp.}

(Figs. 15a-e, 16a-f)

Description, holotype male (left mid leg missing): Body length $2.3 \mathrm{~mm}$. General color pale brown, femora and tibiae similarly pigmented. Eye height $2.5 \times$ genal height. Mid tibia with an anterodorsal seta at basal quarter and an anterodorsal, dorsal and posterodorsal setae at distal 3/4 (proximal anterodorsal area obscured on unique type). Wing veins yellowish brown, third costal sector $0.8 \times$ second costal sector.

Abdomen: Sternite 5 dominated by a prominent trifid posteromedial area made up of a dark, broadly diamondshaped central piece flanked by very broad processes divided into inner and outer surfaces; inner surface densely microtrichose distally and basally with an inward pointed lobe anteroventrally bumpy and apically with a large, stout seta; length anterior to trifid posteromedial area $0.3 \times$ length of S4. Epandrium with two very large lateroventral setae. Cercus convex and rounded, with one long and several shorter setae. Subepandrial sclerite broad and well sclerotized. Surstylus comprising a single strongly curved lobe with three short, very stout preapical anterior setae. Basiphallus broadly cylindrical; distiphallus very short and quadrate, ventrally curved, forked, and pointy, dorsally perpendicularly bent then bilobed; apex with a finely spiculate membranous ventral surface. Postgonite stout, dark, sinuate, more or less parallel sided, bilobed apically.

Etymology: The specific name refers to the strongly curved surstylus.

Type material: Holotype ( $\left.{ }^{\lambda}, \mathrm{QCAZ}\right)$ : ECUADOR: Napo: SierrAzul Lodge, $14 \mathrm{~km}$ W Cosanga, $2200 \mathrm{~m}$, 040'55”S, 7756'9”W, in bamboo stipules, 10.v.2002, S.A. Marshall debu00195563.

\section{Acknowledgments}

Steven Paiero provided the photograph of the type locality and helped with specimen preparation. Jim McClarin, Veronica Crespo, Clifford Keil and Giovanni Onore provided critical assistance with permits and transport of specimens. Jose Simbana, Manager of the Yanayacu Biological Research Station, guided us to different bamboo species in the Yanayacu area and helped with their identification. Andrew Young, Jeremy deWaard and Jeffrey Skevington provide their knowledge and expertise on the molecular aspect of this project. Jindřich Roháček and an anonymous reviewer provided valuable comments that improved this manuscript. 


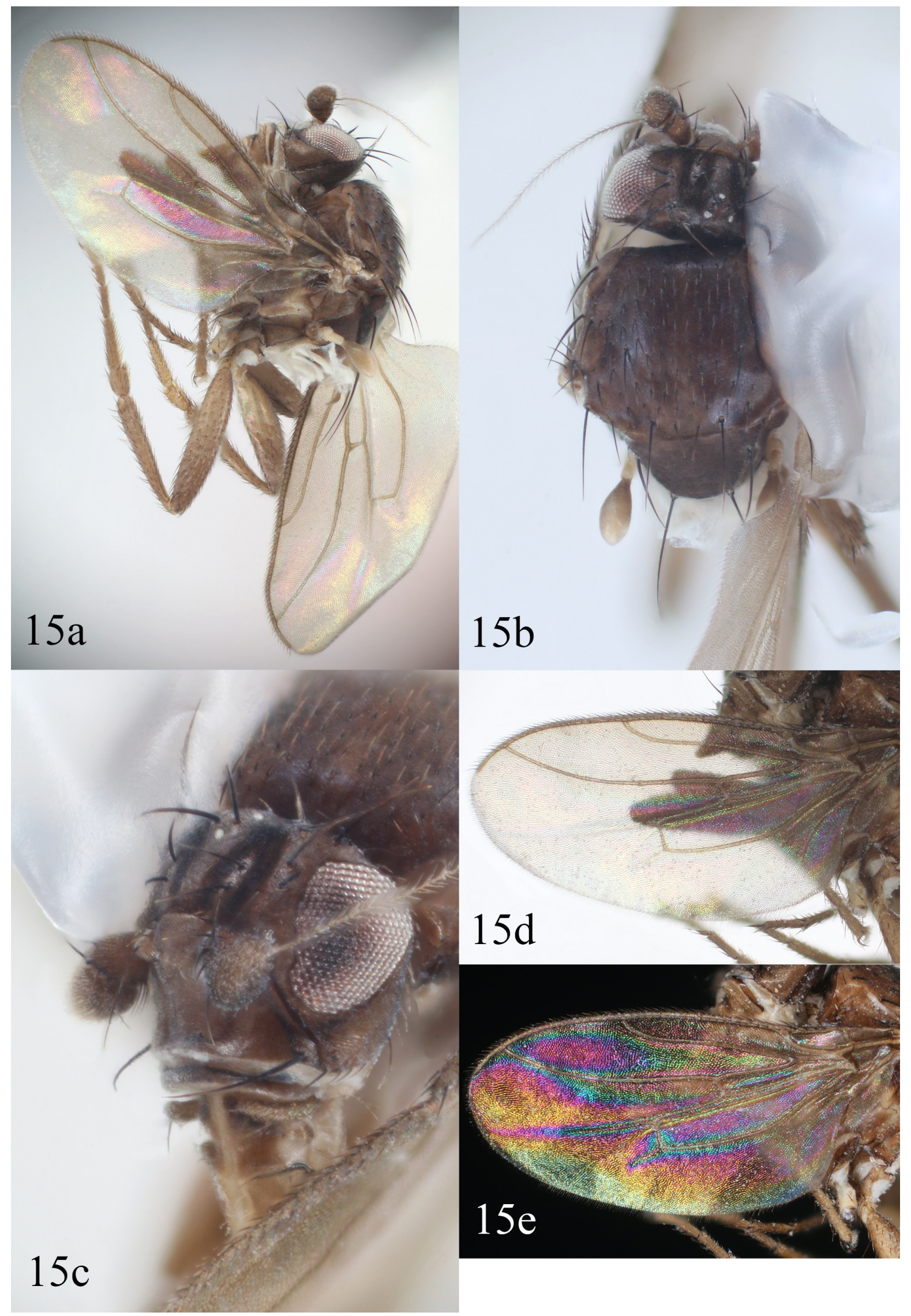

FIGURES 15a-e. Stipulosina curvistylus sp. n. male habitus. 15a, lateral; 15b, dorsal; 15c, head; 15d, wing against white background; 15e, wing displaying WIPs against black background. 


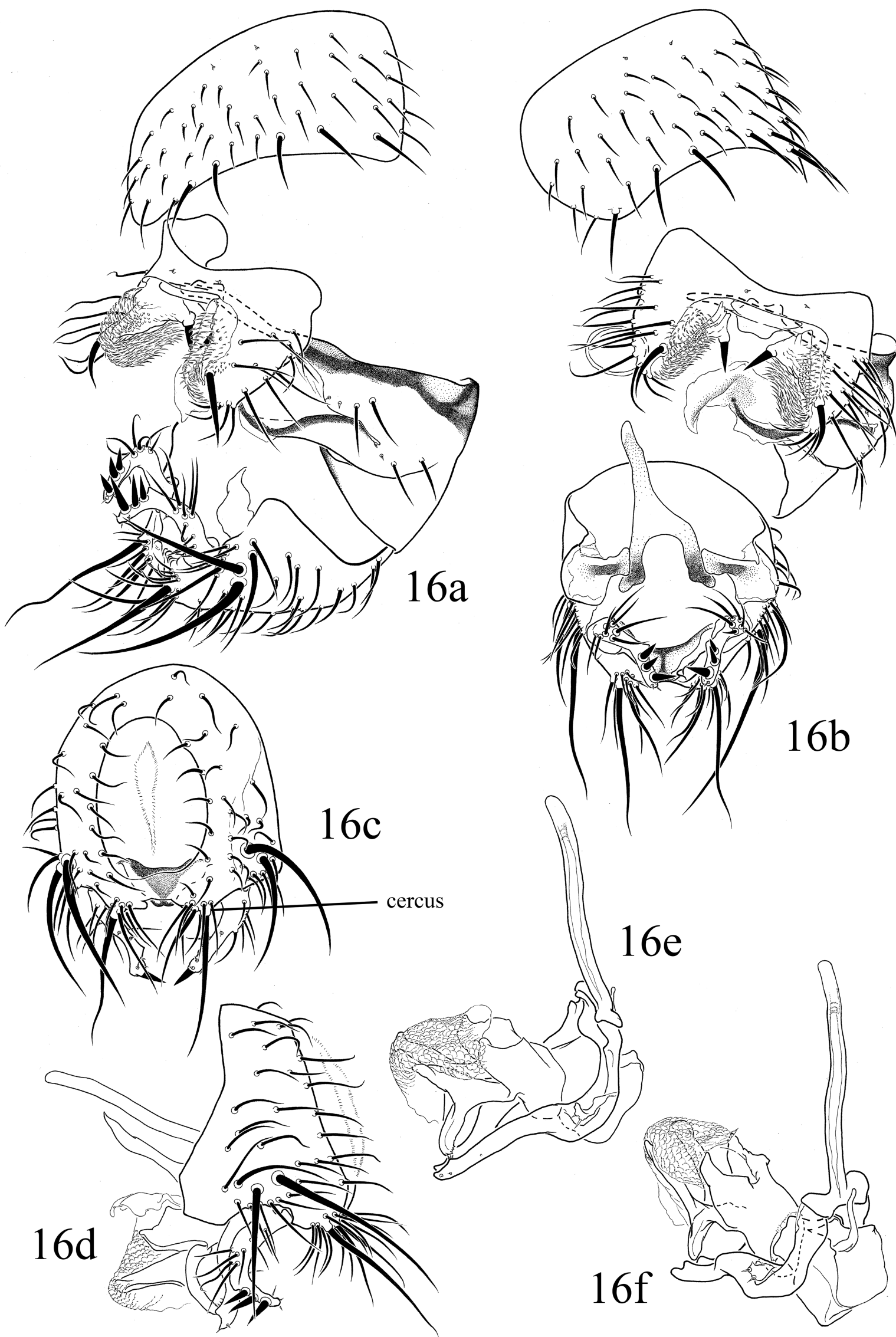

FIGURES 16a-f. Stipulosina curvistylus sp. n. male abdomen. 16a, terminalia left ventrolateral; 16b, terminalia ventral; 16c, epandrium posterior; 16d, epandrium lateral; 16e, phallus and associated structures left ventrolateral; 16f, phallus and associated structures left dorsolateral. 


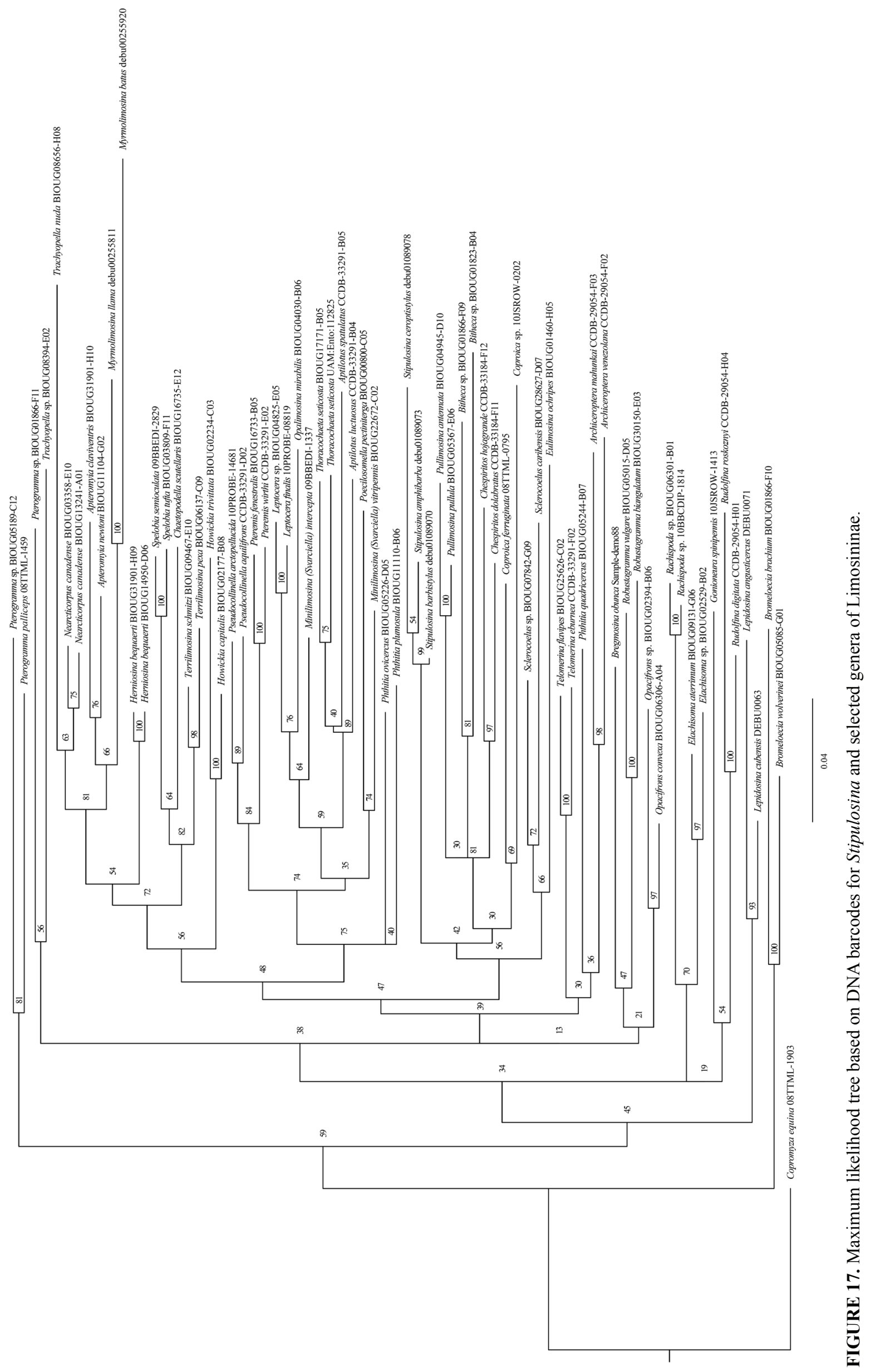




\section{Literature cited}

Calderón, C.E. \& Soderstrom, T.R. (1980) The genera of Bambusoideae (Poaceae) of the American continent: keys and comments. Smithsonian contributions to botany, 44, 1-27. https://doi.org/10.5479/si.0081024X.44

Cumming, J.M. \& Wood, D.M. (2017) Adult morphology and terminology. In: Kirk-Spriggs, A.H. \& Sinclair, B.J. (Ed.), Manual of Afrotropical Diptera. Vol. 1. Introductory chapters and keys to Diptera families. Suricata 4. South African National Biodiversity Institute, Pretoria, pp. 89-133.

Hoang, D.T., Chernomor, O., von Haeseler, A., Minh, B.Q. \& Vinh, L.S. (2018) UFBoot2: Improving the ultrafast bootstrap approximation. Molecular Biology and Evolution, 35, 518-522. https://doi.org/10.1093/molbev/msx281

Kalyaanamoorthy, S., Minh, B.Q., Wong, T.K.F., von Haeseler, A. \& Jermiin, L.S. (2017) ModelFinder: Fast Model Selection for Accurate Phylogenetic Estimates. Nature Methods, 14, 587-589. https://doi.org/10.1038/nmeth.4285

Kuwahara, G.K. \& Marshall, S.A. (2020) A revision of the Neotropical genus Chespiritos (Diptera: Sphaeroceridae: Limosininae). European Journal of Entomology, 117, 164-189. https://doi.org/10.14411/eje.2020.019

Marshall, S.A. \& Buck, M. (2010) 95. Sphaeroceridae (small dung flies). In: Brown, B.V., Borkent, A., Cumming, J.M., Wood, D.M., Woodley, N.E. \& Zumbado, M.A. (Ed.), Manual of Central American Diptera. Vol. 2. NRC Research Press, Ottawa, pp. 1165-1187.

Miller, M.A., Pfeiffer, W. \& Schwartz, T. (2010) Creating the CIPRES Science Gateway for inference of large phylogenetic trees. Proceedings of the Gateway Computing Environments Workshop (GCE), 2010, 1-8. https://doi.org/10.1109/GCE.2010.5676129

Nguyen, L.T., Schmidt, H.A., von Haeseler, A. \& Minh, B.Q. (2015) IQ-TREE: A fast and effective stochastic algorithm for estimating maximum likelihood phylogenies. Molecular Biology and Evolution, 32, 268-274. https://doi.org/10.1093/molbev/msu300

Rambaut, A. (2009) FigTree, version 1.4.4. Computer program distributed by the author, Available from: http://tree.bio.ed.ac. uk/software/figtree/ (accessed 4 November 2020)

Ruiz-Sanchez, E., Clark, L.G., Londoño, X., Mejía-Saulés, T. \& Cortésrodríguez, G. (2015) Morphological keys to the genera and species of bamboos (Poaceae: Bambusoideae) of Mexico. Phytotaxa, 236 (1), 1-24. https://doi.org/10.11646/phytotaxa.236.1.1

Yau, T. \& Marshall, S.A. (2015) Enzymatic clearing agents as an alternative approach to macerating Diptera specimens. Fly Times, 55, 11-12.

Yau, T. \& Marshall, S.A. (2018) A revision of the genus Bromeloecia Spuler (Diptera: Sphaeroceridae: Limosininae). Zootaxa, 4445 (1), 1-115.

https://doi.org/10.11646/zootaxa.4445.1.1 